\title{
Carbon and Biodiversity Outcomes under Divergent Management Scenarios in Shifting Cultivation Landscapes in the Upland Philippines
}

Sharif A. Mukul1,2*, John Herbohn², Jennifer Firn", Nestor Gregorio ${ }^{2}$

${ }^{1}$ Tropical Forests and People Research Centre, University of the Sunshine Coast, Maroochydore, QLD 4558, Australia

${ }^{2}$ Centre for Research on Land-use Sustainability, Dhaka 1229, Bangladesh

${ }^{3}$ School of Earth, Environmental and Biological Sciences, Faculty of Science and Engineering, Queensland University of Technology, Brisbane, QLD 4001, Australia

*Corresponding author: smukul@usc.edu.au / sharif_a_mukul@yahoo.com

\begin{abstract}
The Philippines is both a biodiversity hotspot and a megadiverse country. The country also has experienced one of the highest rates of deforestation in Southeast Asia and is among the first countries to introduce a massive reforestation program to address the country's rapid biodiversity and forest loss. Drawing upon an empirical study from the Leyte island and other relevant case studies from the Philippines, in this chapter, we demonstrate that recovering secondary forests following shifting cultivation, locally known as kaingin have the high potentials for biodiversity and carbon co-benefits. Based on our empirical study, we also found that secondary forest regrowing after kaingin use can potentially be used as a cost-effective reforestation measure with multiple benefits to people and the environment in upland areas of the Philippines. We also discuss measures that are essential for such programs to be successful.
\end{abstract}

Keywords: shifting cultivation, Philippines, biodiversity, carbon, REDD+ 


\section{Introduction}

The Philippines is both a biodiversity hotspot and a megadiverse country (Posa et al. 2008; Myers et al. 2000). The country also has experienced one of the highest rates of deforestation in Southeast Asia and is among the first countries to introduce a massive reforestation program to address the country's rapid biodiversity and forest loss (Pulhin et al. 2007; Chokkalingam et al. 2006). Shifting cultivation, locally termed as kaingin is a widespread land-use in the Philippines (Kummer 1992). It is also a major livelihood strategy to many smallholder farmers living in the remote rural areas of the country (Mukul 2016; Herbohn et al. 2014). However, alike many other tropical countries, major forestry policies in the Philippines have attempted to impose restrictions on kaingin, based on the assumption that it has detrimental impacts on the environment (Saurez and Sajise 2010; Lawrence 1997).

In the Philippines, 53 percent of lands are considered as forest based on the national land classification system (i.e. areas with a slope above 18\%, irrespective of forest cover) (Jahn and Asio 2001). Upland areas in the country, comprise approximately 55 percent of the total land area and are important mostly because they have majority of the remaining forests of the country and they have been subject to intensive use by humans as well as undergone severe land degrdation (Cramb 1998). In the upland areas, kaingin is a prominent land-use and can be categorized into three distinct types based on the sites where they have been practiced, i.e. i) the tubigan system, ii) the katihan system and iii) the dabilig system (Olofson 1980). The tubigan and katihan systems are practiced in lower elevation areas or on gently sloping land with limited irrigation facilities, whereas the dabilig system is widely practiced in heavily forested areas and on steeper slopes (Olofson 1980). 


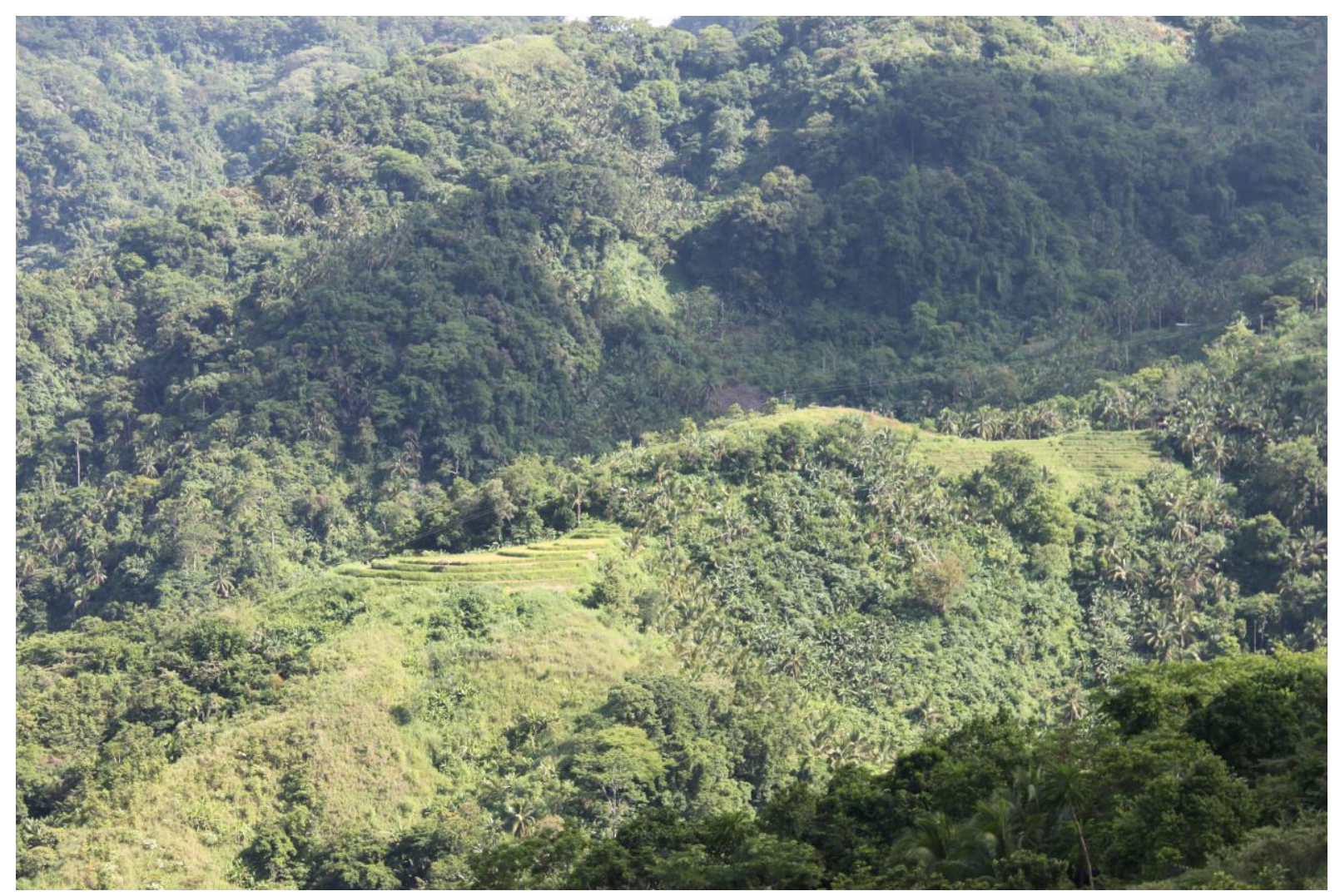

Figure 1. A typical upland landscape in the Philippines with complex mosaics of secondary regrowth, rice paddy field, coconut plantation, disturbed and old-growth forests (Photo: Sharif A. Mukul).

The Philippines, although, is one of the pioneers in large-scale forest landscape restoration (FLR), access by smallholder and subsistence farmers to such efforts remains still very limited (Le et al. 2014). The kaingin land-use, therefore, will continue to form an imperative land-use in the upland areas of the country until greater access to such state regulated reforestation programs will be secured to local communities under community forestry or other participatory schemes (Mukul et al. 2016a; Pulhin et al. 2007). The secondary fallow forests regrowing after kaingin are generally not viewed as suitable targets for biodiversity conservation and carbon retention in the country. Drawing upon an empirical study from the Leyte island and other relevant case studies from the Philippines, in this chapter, we demonstrate that recovering secondary forests following kaingin have the high potentials for biodiversity and carbon co-benefits. Based on our empirical study, we also found that, secondary forest regrowing after kaingin use can potentially be used as a cost effective reforestation measure with multiple benefits to people and environment in upland areas of the Philippines. We also discuss measures that are essential for such programs to be successful. 


\section{The Leyte island}

We conducted the study on the island of Leyte, the Philippines (Figure 2). The island covers an area of about 800,000 hectare (ha) the eighth largest in the country. The major cash crop of the island include coconut (Cocos nucifera), abaca (Musa textilis) and maize (Zea mays). Geographically, the island is located between $124^{\circ} 17^{\prime}$ and $125^{\circ} 18^{\prime}$ East longitude and between $9^{\circ} 55^{\prime}$ and $11^{\circ} 48^{\prime}$ North latitude. The island receives relatively even distribution of rainfall throughout the year with an annual rainfall of about 4,000 $\mathrm{mm}$ (Jahn and Asio 2001). The mean annual temperature is $28^{0} \mathrm{C}$, which remains constant throughout the year (Navarrete et al. 2013).

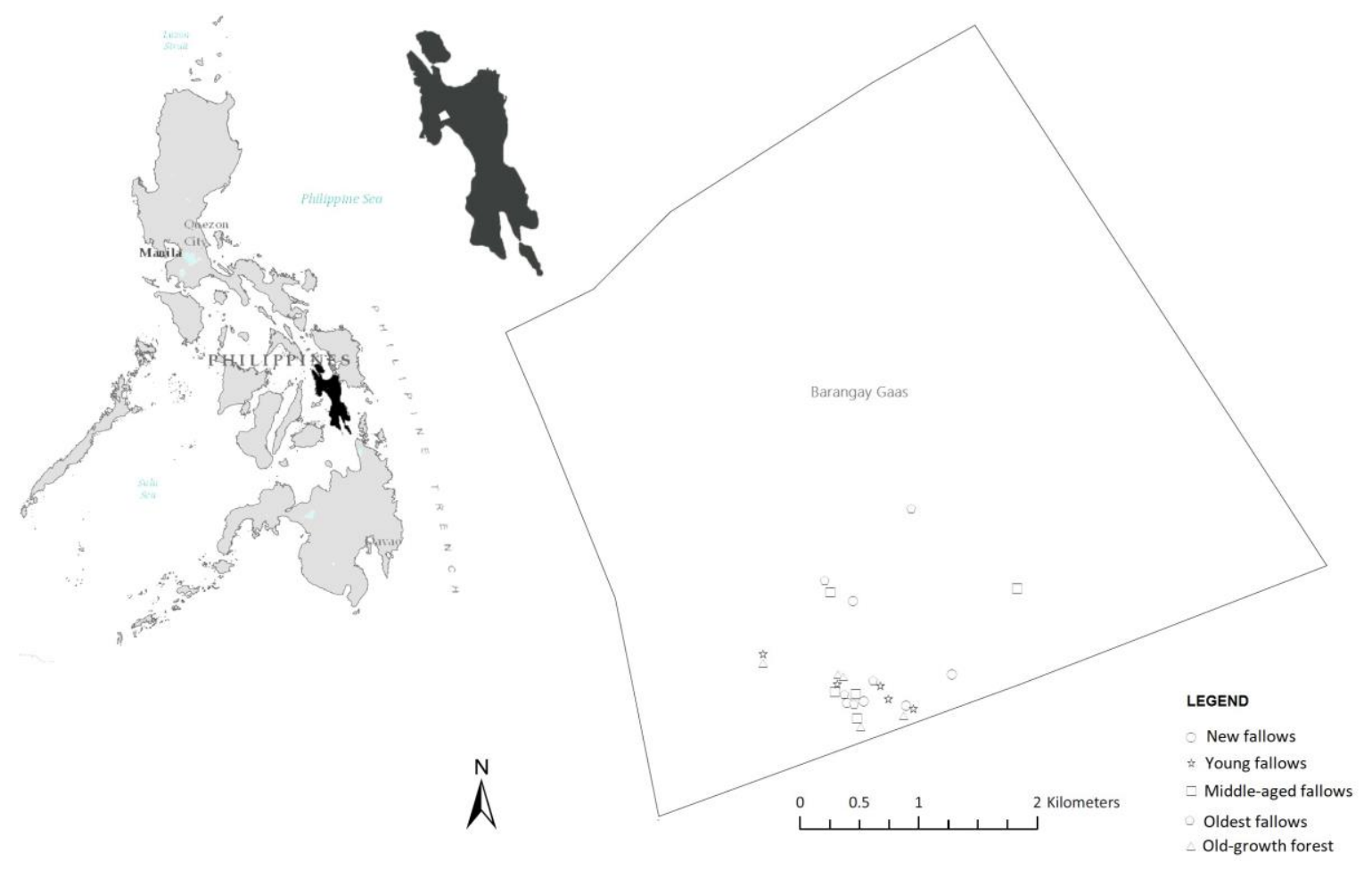

Figure 2. Location of the study sites on Leyte island, the Philippines.

For the ecological survey, we purposively selected Barangay (the smallest administrative entity, similar to a village in the Philippines) Gaas since the area is situated in a comparatively high altitudinal range with a relatively greater extent of undisturbed forests and with low population density. Both of these factors favor the regeneration of kaingin fallow into secondary forests (Chazdon 2014). Smallholder's living in the area usually grow abaca or coconut in their fallow kaingin landscape during the time of abandonment to receive some financial gain. 




Figure 3. A kaingin fallow area being used for abaca (Musa textilis) production in the study area on Leyte island, the Philippines (Photo: Sharif A. Mukul).

\section{Ecological surveys}

Our survey was confined to kaingin fallow areas that were at least 1 ha in size. We categorized our fallow sites into four different categories; i.e. new fallow sites ( $0-5$ year old), young fallow sites (610 year old), middle-aged fallow sites (11-20 year old) and oldest fallow sites (21-30 year old). We took five replicates for each fallow class with old-growth natural forests as our control. In each of our study sites we identified tree species that were at least $5 \mathrm{~cm}$ at dbh (diameter at breast height) and measured diameter and height. More about our survey design and data collection can be found at Mukul (2016). 

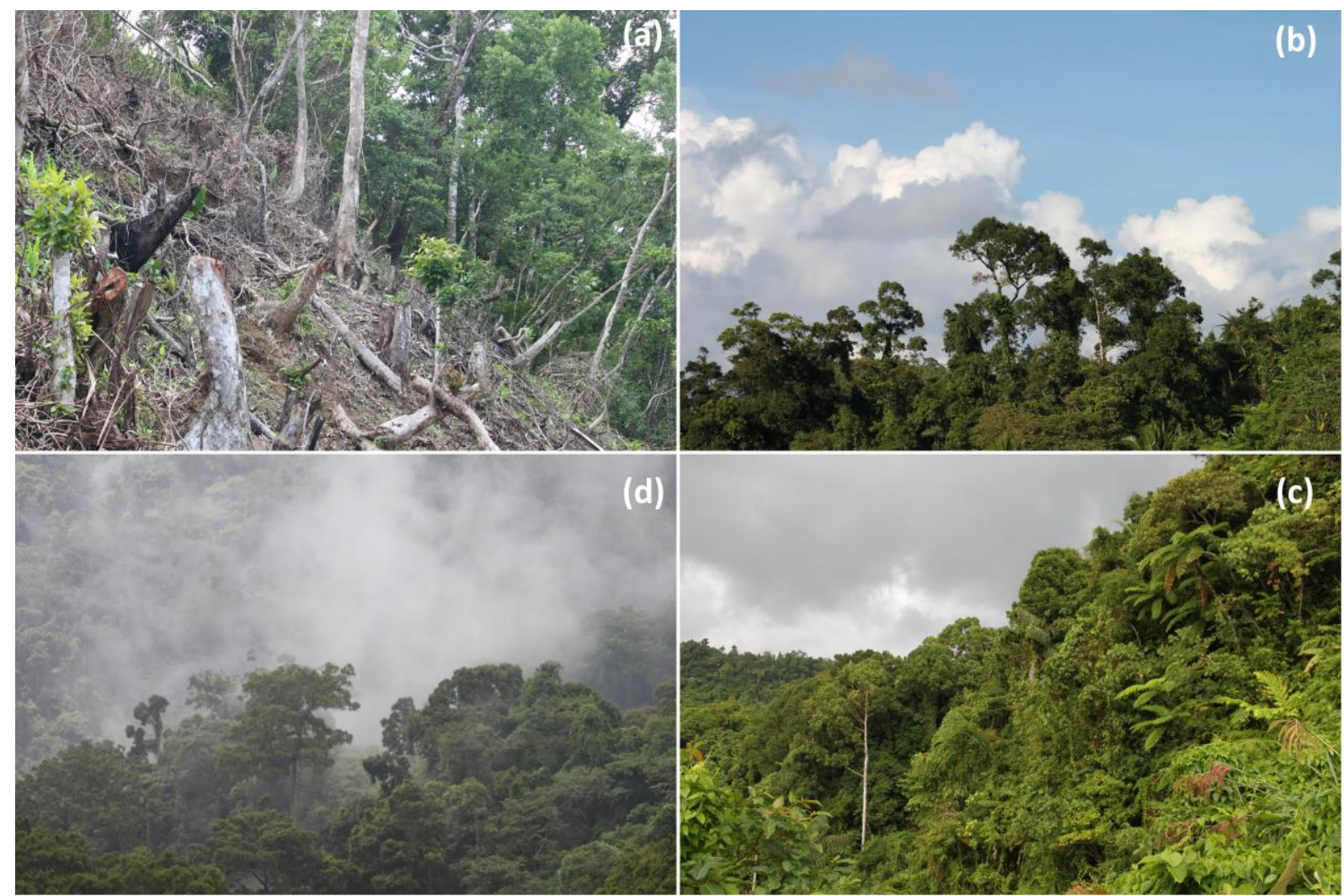

Figure 4. Snapshots of different sites in the area (clockwise): (a) a newly opened kaingin site, (b) a middle-aged fallow site, (c) oldest kaingin fallow site and (d) old-growth control forest (Photo: Sharif A. Mukul).

\section{Biodiversity and carbon measurments, and trade-off analysis}

We used tree species diversity, i.e. number of unique tree species per unit area as a measure of biodiversity. Above ground biomass was estimated as per ha basis following the generic allometric equation developed by Chave et al. (2014) and was expressed in Mega grams (Mg). We used localized wood density estimates from our study sites and carbon content was assumed as 50 percent of the dry woody biomass (see Mukul et al. 2016b).

For biodiversity/carbon trade-off analysis (measured as the additionality $(\Delta)$ ) of different related land-use/cover we used the median value for tree species diversity and biomass carbon for each land-use/cover (i.e. different fallow sites, old-growth control forest, plantation forest).

Additionality was measured as the difference (of biodiversity and carbon) between our control old-growth forest sites and other related land-use/cover (including our regrowing kaingin fallow sites) reported from the Philippines. The value could be either positive (+) or negative (-). 


\section{Biodiversity and carbon co-benefits and trade-offs associated with related land- use/cover in the upland Philippines}

We found highest biodiversity (i.e. tree species density) in our oldest kaingin fallow sites followed by in control old-growth forests, middle-aged fallow sites and young fallow sites (Figure 5).

Aboveground biomass carbon was significantly higher $(P<0.01)$ in our control old-growth foest sites compared to all other kaingin fallow sites (Figure 6).

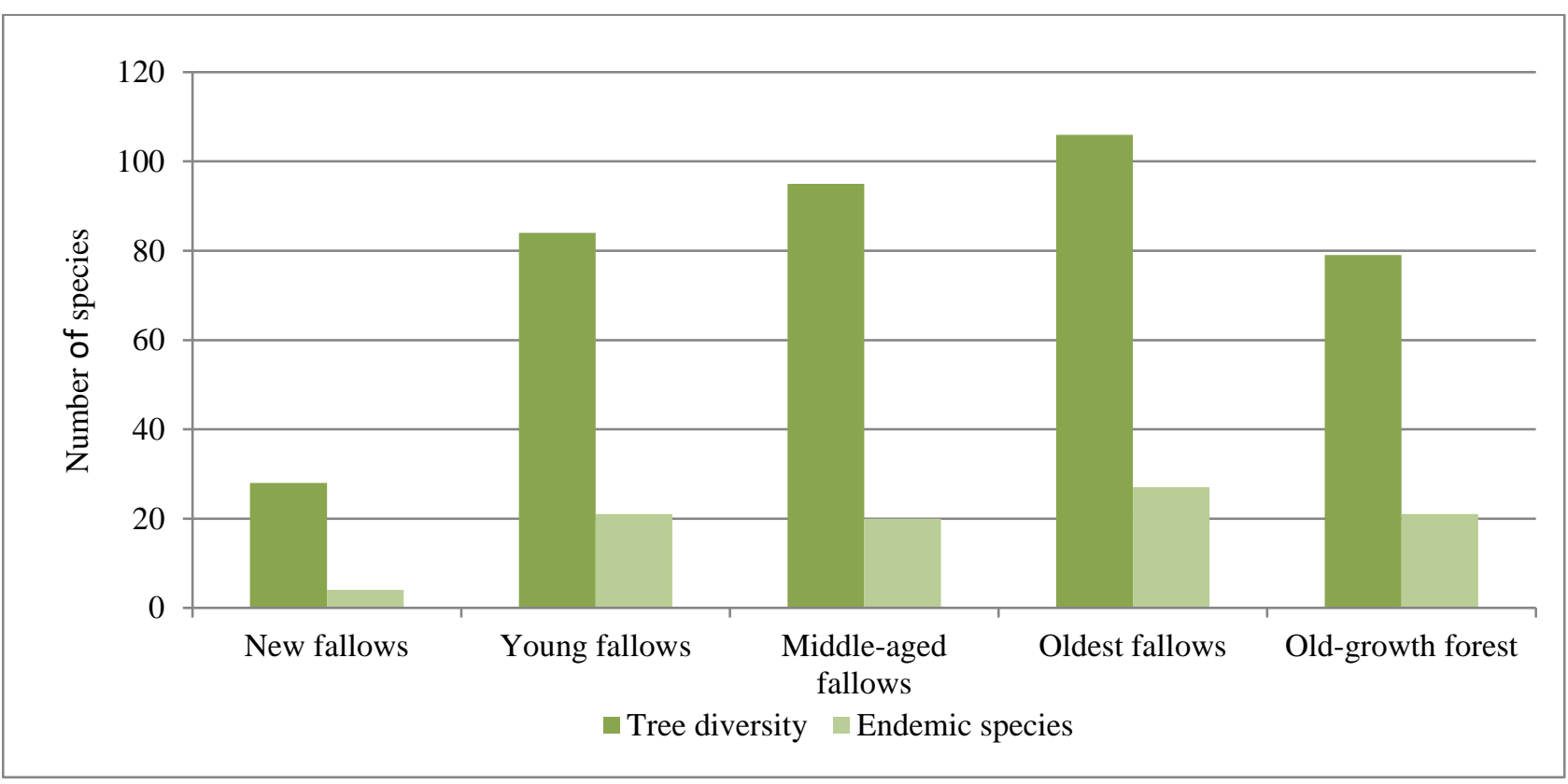

Figure 5. Tree diversity in regrowing secondary forest sites (after kaingin abandonment) and oldgrowth forest on Leyte island, the Philippines. 




Figure 6. Aboveground biomass carbon in regrowing secondary forest sites (after kaingin abandonment) and old-growth forest on Leyte island, the Philippines.

In Table 1 we present the potential biodiversity/ carbon trade-offs associated with related land-use cover (i.e. land-use/cover that may replace kaingin landsdcapes after abandonment) in the upland Philippines. Apparently, old-growth forest always provided the highest carbon benefits $(380.49 \mathrm{Mg}$ $\mathrm{C} / \mathrm{ha}$ ) when compared with other common land-use cover in the Philippines uplands. Biodiversity was although highest in our oldest (i.e. 21-30 year old) fallow kaingin sites, the number of endemic species (i.e species native to the country) was highest in the old-growth forest sites. The 80 year old Swietenia macrophylla plantation had the nearest carbon stock $(264.0 \mathrm{Mg} \mathrm{C} / \mathrm{ha})$ to the old-growth forest, followed by a mixed plantation of Parashorea malaanona and Anisoptera thurifera of the similar age, and kaingin fallow sites of different ages (Table 1). The high level of aboveground biomass carbon in new fallow sites was, however, mainly attributed to high level of coarse dead wood remaining after forest clearing.

The conservation value of different plantations in the country were very low compared to kaingin fallow secondary forests (see Table 1). Only our oldest fallow kaingin sites had the potential to provide relatively similar biodiversity and carbon co-benefits compared to old-growth forests. As expected, agricultural land-use (e.g. rice paddy and sugarcane) and plantations of commercially important species such as oil palm, coconut, and fast growing Gmelina arborea, Albiria falcataria, and Acacia sp. also had lower conservation values and less importance for carbon sequestration than fallow forests regrowing after kaingin use or the native dipterocarp forest (Table 1). The 
Table 1. Biodiversity/ carbon stocks and associated trade-offs in common land-use/cover in the upland Philippines.

\begin{tabular}{|c|c|c|c|c|c|c|}
\hline \multirow[t]{2}{*}{ Land-use/cover } & \multirow{2}{*}{$\begin{array}{l}\text { Tree } \\
\text { diversity }^{1}\end{array}$} & \multirow{2}{*}{$\begin{array}{l}\text { Carbon }^{2} \\
\left(\mathrm{Mg} \mathrm{C} \mathrm{ha-1)}^{-1}\right)\end{array}$} & \multicolumn{2}{|c|}{ Additionality $^{3}(\Delta)$} & \multirow[t]{2}{*}{ Age $^{4}$} & \multirow[t]{2}{*}{ Source(s) } \\
\hline & & & $\triangle$ Biodiversity & $\triangle$ Carbon & & \\
\hline Old-growth forest & 45 & 380.49 & - & - & - & Mukul et al. (2016); Mukul (2016) \\
\hline \multicolumn{7}{|l|}{ Post-kaingin forests } \\
\hline New fallow & 5 & 155.1 & -40 & -225.39 & 5 & As above \\
\hline Young fallow & 39 & 87.99 & -6 & -292.5 & 10 & As above \\
\hline Middle-aged & 42 & 135.73 & -3 & -244.76 & 20 & As above \\
\hline Oldest fallow & 47 & 155.71 & +2 & -224.78 & 30 & As above \\
\hline Dipterocarp forest & $\mathrm{NA}$ & 221.0 & - & -159.49 & $\mathrm{NA}$ & Lasco and Pulhin (2009) \\
\hline \multicolumn{7}{|l|}{ Grasslands } \\
\hline Imperata sp. & 0 & 8.5 & -45 & -371.99 & 1 & Lasco and Pulhin (2009) \\
\hline Sacharrum sp. & 0 & 13.1 & -45 & -367.39 & 1 & Lasco and Pulhin (2009) \\
\hline \multicolumn{7}{|l|}{ Plantations } \\
\hline Swietenia macrophylla & 1 & 264.0 & -44 & -116.49 & NA & Racelis et al. (2008) \\
\hline Acacia sp. & 1 & 81.0 & -44 & -299.49 & NA & Lasco and Pulhin (2009) \\
\hline Albizia falcataria & 1 & 48.69 & -44 & -331.8 & 9 & Lasco (2002) \\
\hline Gmelina arborea & 1 & 54.32 & -44 & -326.17 & 9 & Lasco (2002) \\
\hline $\begin{array}{l}\text { Parashorea malaanonan }+ \\
\text { Anisoptera thurifera }\end{array}$ & 2 & 241.25 & -43 & -139.24 & 80 & Lasco and Pulhin (2009) \\
\hline $\begin{array}{l}\text { Parashorea malaanonan }+ \\
\text { Dipterocarpus grandiflorus }\end{array}$ & 2 & 125.61 & -43 & -254.88 & 80 & Lasco and Pulhin (2009) \\
\hline Coconut & 1 & 86.0 & -44 & -294.49 & 30 & Lasco (2002) \\
\hline Oil palm & 1 & 55.0 & -44 & -325.49 & 9 & Pulhin et al. (2014) \\
\hline \multicolumn{7}{|l|}{ Agriculture } \\
\hline Rice paddy & 0 & 3.1 & -45 & -377.39 & 1 & Lasco and Pulhin (2009) \\
\hline Abaca & 0 & 5.7 & -45 & -374.79 & 1 & Lasco (2002) \\
\hline Sugarcane & 0 & 12.5 & -45 & -367.99 & 1 & Lasco and Pulhin (2009) \\
\hline
\end{tabular}

1 here we only consider the main and/or characteristics plant diversity of a particular land-use/cover;

2 aboveground carbon in tree biomass;

3 the difference, either positive or negative between control old-growth forest and respective land-use/cover;

4 stand age;

NA - not available. 
monoculture of fast growing timber species revelaed to have lower carbon benefits compared to mixed plnattaions in the Philippines.

\section{Conclusion and management implications}

Our study revealed that regrowing secondary forest after kaingin use can provide substantial biodiversity and carbon co-benefits when compared with old-growth foress, fast growing timber species, and other commercially important species that may grow on land after kaingin abandonment. While some plantations may also hold superior carbon storage and sequestration potential in tropical region (see Erskine et al. 2006 for example), their conservation value is not comparable as that of old-growth forests and secondary forests regrowing after shifting cultivation abandonment. Moreover, such plantations require high management and maintenance costs (Gregorio et al. 2015).

In tropical region, uncertainties in the forest carbon, their distribution and recovery rate are the main constraints for including secondary forests regrowing after shifting cultivation abandonment in the global voluntary carbon market (Mertz et al. 2012; Ziegler et al. 2012; Mertz 2009). Because of the dynamic nature of secondary forests regrowing after shifting cultivation, the instability of biodiversity and biomass carbon in such landscapes can be an issue (Mukul and Herbohn 2016). In such circumstances, biodiversity and carbon co-benefits can be achieved by either avoiding further landscape degradation from intensification or by promoting natural regeneration. Intensification can be avoided through allowing longer fallow cycles or using multipurpose species that are also common in the forest. Enhancement of natural regeneration, on the other hand, can be achieved through preventing further use of the area for shifting cultivation and by assisted natural regeneration (Chazdon and Guariguata 2016). Our trade-off analysis, in all cases, found that regrowing secondary forests after kaingin use outperforms other land uses and available reforestation measures in the upland Philippines with regard to biodiversity and carbon co-benefits. Population density and growth, however, are some major drivers of intensification of the shifting cultivation system in most of the tropics (van Vliet et al. 2012) which may reduce carbon benefits due to shorter fallow periods and frequent cycles (Lawrence et al. 2010).

Presently, global forest carbon credits are valued at over US\$100 billion/year, and are an emerging, growing sector (Peters-Stanley and Yin 2013; Petrokofsky et al. 2011). In addition, 
policy makers have recently committed to the Bonn Challenge, an iniatiative to restore 150 million ha of degraded forests globally by 2020 and 350 million ha by 2030 (Locatelli et al. 2015). The prospect of inclusion of regrowing secondary forests in the emerging global carbon markets, however, largely depends on the reliable estimates of carbon together with their biodiversity benefits (Law et al. 2015; Maron et al. 2013).

Forest conservation in the Philippines has clearly visible benefits to local livelihoods and climate change mitigation (Lasco et al. 2013; Sheeran 2006). Due to the large areas involved and their importance to smallholders, secondary forests regrowing after shifting cultivation could provide important benefits to both the environment and the local community if properly incorporated in REDD+ (Reducing Emissions from Deforestation and Forest Degradatioin) and CDM (Clean Development Mechanisms) schemes. We found that allowing forests to regenerate naturally after kaingin use can be a cost effective restoration measure in the Philippines, with a high potential for integration into REDD+ and CDM. It is, however, critical to involve local community members in such activities, with clearly defined rights and responsibilities (Mukul et al. 2014). Improving environmental governance through legal and regulatory reform, better land allocation, land tenure and management, law enforcement, and monitoring are also crucial (Baynes et al. 2015; Chazdon 2013; Le et al. 2012).

\section{References}

Baynes, J., Herbohn, J., Smith, C., Fisher, R., Bray, D. 2015. Key factors which influence the success of community forestry in developing countries. Global Environmental Change, 35: $226-238$.

Chave, J., Réjou-Méchain, M., Búrquez, A., Chidumayo, E., Colgan, M.S., Delitti, W.B.C., Duque, A., Eid, T., Fearnside, P.M., Goodman, R.C., Henry, M., Martínez-Yrízar, A., Mugasha, W.A., Muller-Landau, H.C., Mencuccini, M., Nelson, B.W., Ngomanda, A., Nogueira, E.M., Ortiz-Malavassi, E., Pélissier, R., Ploton, P., Ryan, C.M., Saldarriaga, J.G., Vieilledent, G., et al. 2014. Improved allometric models to estimate the aboveground biomass of tropical trees. Global Change Biology, 20: 3177-3190.

Chazdon, R. L., Guariguata, M.R. 2016. Natural regeneration as a tool for large-scale forest restoration in the tropics: prospects and challenges. Biotropica, 48: 844-855.

Chazdon, R.L. 2014. Second growth: the promise of tropical forest regeneration in an age of deforestation. University of Chicago Press, Chicago, IL. 
Chazdon, R.L. 2013. Making tropical succession and landscape reforestation successful. Journal of Sustainable Forestry, 32: 649-658.

Chokkalingam, U., Carandang, A.P., Pulhin, J.M., Lasco, R.D., Peras, R.J.J., Toma, T. (eds.), 2006. One century of forest rehabilitation in the Philippines: Approaches, outcomes and lessons. Centre for International Forestry Research (CIFOR), Bogor, Indonesia.

Cramb, R., 1998. Environment and development in the Philippine uplands: the problem of agricultural land degradation. Asian Studies Review, 22: 289-308.

Erskine, P.D., Lamb, D., Bristow, M. 2006. Tree species diversity and ecosystem function: Can tropical multi-species plantations generate greater productivity? Forest Ecology and Management, 233: 205-210.

Gregorio, N., Herbohn, J., Harrison, S., Smith, C. 2015. A systems approach to improving the quality of tree seedlings for agroforestry, tree farming and reforestation in the Philippines. Land Use Policy, 47: 29-41.

Herbohn, J. L., Vanclay, J. K., Ngyuen, H., Le, H.D., Harrison, S.R., Cedamon, E., Smith, C., Firn, J., Gregorio, N.O., Mangaoang, E., Lamarre, E. 2014. Inventory procedures for smallholder and community woodlots in the Philippines: methods initial findings and insights. Small-scale Forestry, 13: 79-100.

Jahn, R., Asio, V.B. 2001. Climate, geology, geomorphology and soils of the tropics with special reference to Leyte islands (Philippines). In: Proceedings of the 8th International Seminar and Workshop on Tropical Ecology. Visayas State College of Agriculture, Baybay, Leyte, pp. 25-43.

Kummer, D.M. 1992. Upland agriculture, the land frontier and forest decline in the Philippines. Agroforestry Systems, 18: 31-46.

Lasco, R.D. 2002. Forest carbon budgets in Southeast Asia following harvesting and land cover change. Science in China, 45: 55-64.

Lasco, R.D., Pulhin, F.B. 2009. Carbon budgets of forest ecosystems in the Philippines. Journal of Environmental Science and Management, 12: 1-13.

Lasco, R.D., Veridiano, R.K. A., Habito, M., Pulhin, F.B. 2013. Reducing emissions from deforestation and forest degradation plus (REDD+) in the Philippines: will it make a difference in financing forest development? Mitigation and Adaptation Strategies for Global Change, 18: 1109-1124.

Law, E.A., Bryan, B.A., Torabi, N., Bekessy, S.A., McAlpine, C.A., Wilson, K.A. 2015.

Measurement matters in managing landscape carbon. Ecosystem Services, 13: 6-15. 
Lawrence, A., 1997. Kaingin in the Philippines: is it the end of the forest? Rural Development Forestry Network Paper 21, London, UK.

Lawrence, D., Radel, C., Tully, K., Schmook, B., Schneider, L. 2010. Untangling a decline in tropical forest resilience: constraints on the sustainability of shifting cultivation across the globe. Biotropica, 42: 21-30.

Le, H.D., Smith, C., Herbohn, J., Harrison, S. 2012. More than just trees: assessing reforestation success in tropical developing countries. Journal of Rural Studies, 28: 5-19.

Le, H.D., Smith, C., Herbohn, J.L. 2014. What drives the success of reforestation projects in tropical developing countries? The case of the Philippines. Global Environmental Change, 24: 334-348.

Locatelli, B., Catterall, C.P., Imbach, P., Kumar, C., Lasco, R., Marín-Spiotta, E., Mercer, B., Powers, J.S., Schwartz, N., Uriarte, M. 2015. Tropical reforestation and climate change: beyond carbon. Restoration Ecology, 23: 337-343.

Maron, M., Rhodes, J.R., Gibbons, P. 2013. Calculating the benefit of conservation actions. Conservation Letters, 6: 359-367.

Mertz, O. 2009. Trends of shifting cultivation and the REDD mechanism. Current Opinion in Environmental Sustainability, 1: 156-160.

Mertz, O., Müller, D., Sikor, T., Hett, C., Heinimann, A., Castella, J.C., Lestrelin, G., Ryan, C.M., Reay, D.S., Schmidt-Vogt, D., Danielsen, F., Theilade, I., van Noordwijk, M., Verchot, L.V., Burgess, N.D., Berry, N.J., Pham, T.T., Messerli, P., Xu, J., Fensholt, R., Hostert, P., Pflugmacher, D., Bruun, T.B., de Neergaard, A., Dons, K., Dewi, S., Rutishauser, E., Sun, Z. 2012. The forgotten D: challenges of addressing forest degradation in complex mosaic landscapes under REDD+. Danish Journal of Geography, 112: 63-76.

Mukul, S.A. 2016. Shifting cultivation in the upland secondary forests of the Philippines: Biodiversity and carbon stock assessment, and ecosystem services trade-offs in land-use decisions. PhD Thesis, The University of Queensland, Australia.

Mukul, S.A., Herbohn, J. 2016. The impacts of shifting cultivation on secondary forests dynamics in tropics: a synthesis of the key findings and spatio temporal distribution of research. Environmental Science \& Policy, 55: 167-177.

Mukul, S.A., Herbohn, J., Firn, J. 2016a. Co-benefits of biodiversity and carbon sequestration from regenerating secondary forests in the Philippine uplands: Implications for forest landscape restoration. Biotropica, 48: 882-889.

Mukul, S.A., Herbohn, J., Firn, J. 2016b. Tropical secondary forests after shifting cultivation are important carbon sources and sinks. Scientific Reports, 6: 22483. 
Mukul, S.A., Herbohn, J., Rashid, A.Z.M.M., Uddin, M.B. 2014. Comparing the effectiveness of forest law enforcement and economic incentive to prevent illegal logging in Bangladesh. International Forestry Review, 16: 363-375.

Myers, N., Mittermeier, R.A., Mittermeier, C.G., da Fonseca, G.A.B., Kent, J., 2000. Biodiversity hotspots for conservation priorities. Nature, 403: 853-858.

Navarrete, I.A., Tsutsuki, K., Asio, V.B. 2013. Characteristics and fertility constraints of degraded soils in Leyte, Philippines. Archives of Agronomy and Soil Science, 59: 625-639.

Olofson, H. 1980. Swidden and kaingin among the southern Tagalog: a problem in Philippine upland ethno-agriculture. Philippine Quarterly of Culture and Society, 8: 168-180.

Peters-Stanley, M., Yin, D. 2013. Maneuvering the Mosaic: State of the voluntary carbon markets 2013. Forest Trends, Washington, DC and Bloomberge New Energy Finance, New York.

Petrokofsky, G.,Holmgren, P., Brown, N.D. 2011. Reliable forest carbon monitoring systematic reviews as a tool for validating the knowledge base. International Forestry Review, 13: 56-66.

Posa, M.R., Diesmos, A.C., Sodhi, N.S., Brooks, T.M. 2008. Hope for threatened tropical biodiversity: lessons from the Philippines. BioScience, 58: 231-240.

Pulhin, F.B., Lasco, R.D., Urquiola, J.P. 2014. Carbon sequestration potential of Oil palm in Bohol, Philippines. Ecosystems \& Development Journal, 4: 14-19.

Pulhin, J.M., Inoue, M., Enters, T. 2007. Three decades of community-based forest management in the Philippines: Emerging lessons for sustainable and equitable forest management. International Forestry Review, 9: 865-883.

Racelis, E.L., Carandang, W.M., Lasco, R.D., Racelis, D.A., Castillo, A.S.A., Pulhin, J.M. 2008. Assessing the carbon budgets of large leaf mahogany (Swietenia macrophylla King) and Dipterocarp plantations in the Mt. Makiling Forest Reserve, Philippines. Journal of Environmental Science and Management, 11: 40-55.

Sheeran, K.A. 2006. Forest conservation in the Philippines: A cost effective approach to mitigating climate change? Ecological Economics, 58: 338-349.

Suarez, R.K., Sajise, P.E. 2010. Deforestation, swidden agriculture and Philippine biodiversity. Philippine Science Letters, 3: 91-99.

van Vliet, N., Mertz, O., Heinimann, A., Langanke, T., Pascual, U., Schmook, B., Adams, C., Schmidt-Vogt, D., Messerli, P., Leisz, S., Castella, J.C., Jørgensen, L., Birchthomsen, T., Hett, C., Bech-Bruun, T., Ickowitz, A., Vu, K.C., Yasuyuki, K., Fox, J., Padoch, C., Dressler, W., Ziegler, A.D. 2012. Trends, drivers and impacts of changes in swidden 
cultivation in tropical forest-agriculture frontiers: a global assessment. Global Environmental Change, 22: 418-429.

Ziegler, A.D., Phelps, J., Yuen, J.Q., Webb, E.L., Lawrence, D., Fox, J.M., Bruun, T.B., Leisz, S.J., Ryan, C.M., Padoch, C., Koh, L.P. 2012. Carbon outcomes of major land-cover transitions in SE Asia: great uncertainties and REDD+ policy implications. Global Change Biology, 18: 3087-3099. 